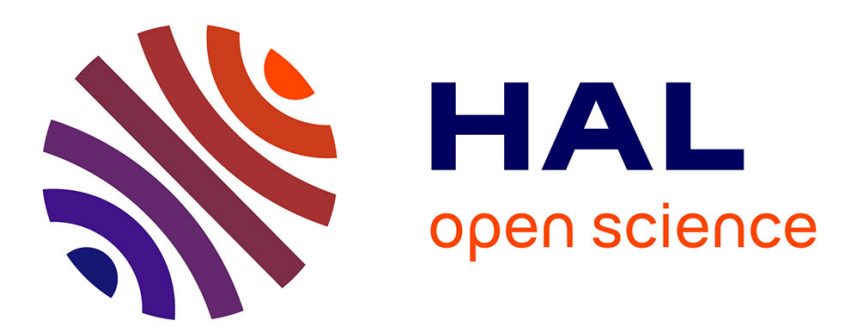

\title{
Synthesis of 2,5-Diiodopyrazine by Deprotonative Dimetalation of Pyrazine
}

Jean-Martial L'Helgoual'Ch, Ghenia Bentabed-Ababsa, Floris Chevallier, Aïcha Derdour, Florence Mongin

\section{> To cite this version:}

Jean-Martial L'Helgoual'Ch, Ghenia Bentabed-Ababsa, Floris Chevallier, Aïcha Derdour, Florence Mongin. Synthesis of 2,5-Diiodopyrazine by Deprotonative Dimetalation of Pyrazine. Synthesis: Journal of Synthetic Organic Chemistry, 2008, 24, pp.4033-4035. 10.1055/s-0028-1083218 . hal01010345

HAL Id: hal-01010345

\section{https://hal-univ-rennes1.archives-ouvertes.fr/hal-01010345}

Submitted on 27 Jun 2014

HAL is a multi-disciplinary open access archive for the deposit and dissemination of scientific research documents, whether they are published or not. The documents may come from teaching and research institutions in France or abroad, or from public or private research centers.
L'archive ouverte pluridisciplinaire HAL, est destinée au dépôt et à la diffusion de documents scientifiques de niveau recherche, publiés ou non, émanant des établissements d'enseignement et de recherche français ou étrangers, des laboratoires publics ou privés. 


\title{
Synthesis of 2,5-Diiodopyrazine by Deprotonative Dimetalation of Pyrazine
}

\author{
Jean-Martial L'Helgoual'ch, ${ }^{\mathrm{a}}$ Ghenia Bentabed-Ababsa, ${ }^{\mathrm{a}, \mathrm{b}}$ Floris Chevallier, ${ }^{\mathrm{a}}$ Aïcha Derdour ${ }^{\mathrm{b}}$ and Florence Mongin ${ }^{\mathrm{a}}$ \\ ${ }^{\text {a }}$ Chimie et Photonique Moléculaires, UMR 6510 CNRS, Université de Rennes 1, Bâtiment 10A, Case 1003, Campus Scientifique de \\ Beaulieu, 35042 Rennes, France \\ ${ }^{\mathrm{b}}$ Laboratoire de Synthèse Organique Appliquée, Faculté des Sciences de l'Université, BP 1524 Es-Senia, Oran 31000, Algeria \\ Fax: +33(0)223236955. \\ E-mail: florence.mongin@univ-rennes1.fr.
}

Received: The date will be inserted once the manuscript is accepted.

\begin{abstract}
The deproto-metalation reactions of pyrimidine and pyrazine were regioselectively carried out using lithium tri(2,2,6,6-tetramethylpiperidino)cadmate in tetrahydrofuran at room temperature. This result was demonstrated by subsequent trapping with iodine to afford 4-iodopyrimidine and iodopyrazine in 71 and $63 \%$ yields, respectively. The same reaction performed on pyridazine afforded a mixture of the 3- and 4-iodo derivatives ( 55 and $41 \%$ yields, respectively). From pyrazine, the access to the 2,5-diiodo derivative ( $40 \%$ on a $25 \mathrm{mmol}$ scale) proved possible using a larger amount of base (1 equiv instead of 1/3).
\end{abstract}

Key words: Metalations, Cadmium, Lithium, Heterocycles, Iodine.

\section{Procedure 1}

$$
\begin{aligned}
& \text { 1) } 1 \text { equiv } \mathrm{CdCl}_{2} \cdot \text { TMEDA } \\
& +3 \text { equiv LiTMP } \\
& \text { THF, rt, } 2 \mathrm{~h} \\
& \text { 2) } \mathrm{I}_{2} \\
& {[]^{N}} \\
& \underset{\substack{25 \mathrm{mmol} \text { scale } \\
40 \% \text { yield }}}{\longrightarrow}
\end{aligned}
$$

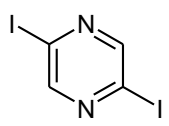

\section{Introduction}

The preparation of functionalized diazines is an important synthetic goal because of the multiple applications of these molecules. ${ }^{1}$

Deprotonative metalation has been widely used as a powerful method for the regioselective metalation of aromatic rings, and various strong bases such as alkyllithiums and lithium dialkylamides have been employed for this purpose. ${ }^{2}$ Even with the latter, either extremely low reaction temperatures or in situ electrophilic trapping are required for aromatics bearing reactive functions (e.g. ester or cyano groups) or sensitive $\pi$-deficient heterocycles due to the high reactivity of the corresponding (hetero)aryllithiums.

The use of additives for lithium compounds in order to modify their behavior ("synergy") is a challenging field. Various $\mathrm{R}_{\mathrm{n}} \mathrm{MLi}$-type compounds have been prepared, such species exhibiting properties that cannot be attained by the homometallic compounds on their own.

Well-known examples are the powerful mixtures of organolithiums and alkoxides ( $\mathrm{M}=$ alkali metal) described by Schlosser, ${ }^{3}$ Lochmann ${ }^{4}$ and Caubère ${ }^{5}$.

More recently, $\mathrm{R}_{\mathrm{n}} \mathrm{MLi}$-type compounds ( $\mathrm{M}=$ non-alkali metal) have been developed. These species, present in stoichiometric $^{6}$ or catalytic ${ }^{7}$ amount in reaction mixtures, display a large panel of reactivities depending on both the metal $\mathrm{M}$ and the groups connected to it.
By combining soft organometallic compounds with alkali additives such as LiTMP (TMP $=2,2,6,6$ tetramethylpiperidino) or $\mathrm{LiCl}$, bases $\left({ }^{t} \mathrm{Bu}_{2} \mathrm{Zn}(\mathrm{TMP}) \mathrm{Li}^{8}\right.$ and $(\mathrm{TMP})_{2} \mathrm{Zn} \cdot 2 \quad \mathrm{MgCl}_{2} \cdot 2 \mathrm{LiCl}^{7 \mathrm{~b}}$ respectively) have been prepared and used for the deproto-metalation of sensitive aromatic substrates.

Metalation of diazines is a difficult challenge due to very facile nucleophilic addition reactions in relation with the low LUMO energy levels of these substrates. Recourse to hindered dialkylamides such as lithium diisopropylamide (LiDA) and lithium 2,2,6,6-tetramethylpiperidide (LiTMP) allowed numerous substituted diazines to be deprotonated. ${ }^{9}$ Without substituent, reactions are less obvious. Metalation of pyrazine and pyridazine was found possible with an excess of LiTMP and very short reaction times at very low temperatures, while metalation of pyrimidine could only be accomplished using the in situ trapping technique. ${ }^{10}$ Kondo described in 2003 the unprecedented regioselective functionalization of pyridazine and pyrimidine at positions 4 and 5, respectively, using hindered phosphazene $t \mathrm{Bu}-\mathrm{P} 4$ base and $\mathrm{ZnI}_{2}$ as additive in toluene, and in the presence of a carbonylated compound as electrophile. ${ }^{11}$ Knochel has reported since 2006 the use of mixed lithium-magnesium amides such as (TMP) $\mathrm{MgCl} \cdot \mathrm{LiCl}$ for the deprotonation of diazines; ${ }^{7 \mathrm{a}, 12}$ the method is powerful, but it still requires low temperatures, and has not been used for unsubstituted substrates.

We recently observed that the metalation of all the unsubstituted diazines could be performed at room temperature or more in tetrahydrofuran (THF) using a mixture of (TMP) ${ }_{2} \mathrm{Zn}$ and LiTMP (0.5 equiv each), in situ prepared from $\mathrm{ZnCl}_{2} \cdot$ TMEDA $^{13}$ (0.5 equiv) and LiTMP (1.5 equiv), a result evidenced by trapping with iodine (Scheme 1). ${ }^{14}$

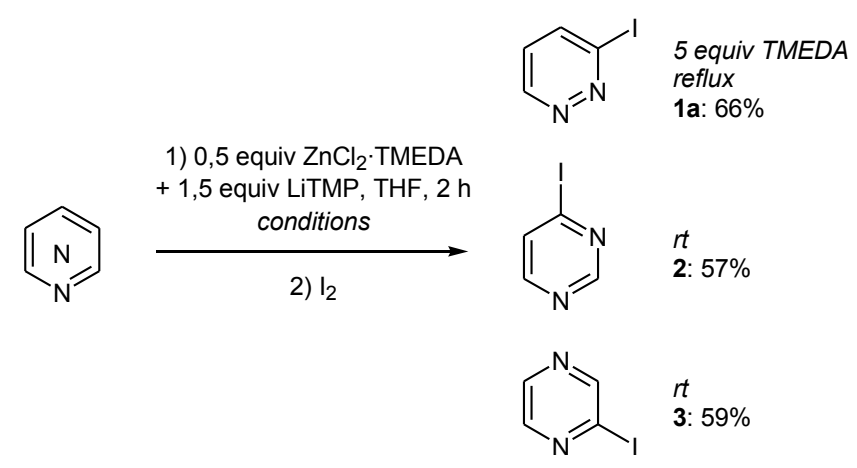

Scheme 1 
In order to seek out a more efficient reagent to deprotometalate diazines, we focused the reaction using the corresponding mixture with cadmium instead of zinc. ${ }^{15}$ Indeed, Wittig and co-workers observed in 1951 that the efficiency of deprotonation reactions of fluorene using different $\mathrm{Ph}_{3} \mathrm{MLi}$ reagents was in relation with the size of the central metal M. In particular, quenching with $\mathrm{CO}_{2}$ and subsequent acidic work-up afforded diphenyleneacetic acid in a low $16 \%$ yield after 10 days reaction time using $\mathrm{Ph}_{3} \mathrm{ZnLi}$ as base whereas a satisfying $64 \%$ yield was obtained after 3 days using $\mathrm{Ph}_{3} \mathrm{CdLi}^{16}$

In contrast to the corresponding $\mathrm{Zn}-\mathrm{Li}$ base, the in situ prepared mixture of $\mathrm{CdCl}_{2} \cdot \mathrm{TMEDA}^{17}$ and LiTMP (3 equiv) seems to provide a lithium ate compound. ${ }^{15}$

\section{Scope and Limitations}

Attempts to metalate pyridazine, pyrimidine or pyrazine indicated that the Cd-Li base was suitable for an efficient reaction in THF at room temperature. Indeed, subsequent trapping with iodine after $2 \mathrm{~h}$ afforded substituted derivatives in satisfying yields. Whereas 4-iodopyrimidine (2) was regioselectively formed from pyrimidine $(x=$ $0.5)$, a mixture of 3- and 4-iodopyridazine $(\mathbf{1 a}, \mathbf{b})$ was obtained from pyridazine $(x=1)$ in a $60 / 40$ ratio (Scheme 2).

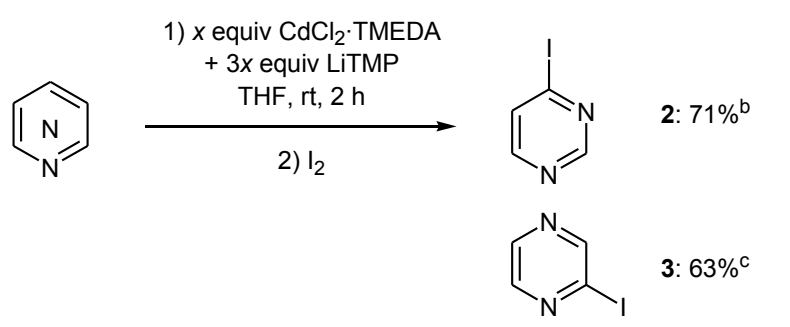

Scheme $2{ }^{\mathrm{a}} x=1 .{ }^{\mathrm{b}} x=0.5{ }^{\mathrm{c}} x=0.33$.

Iodopyrazine (3) was isolated in $63 \%$ yield using $\mathrm{CdCl}_{2}$. TMEDA ( $x=0.33$ equiv) and LiTMP $(3 x=1$ equiv). If the amounts of $\mathrm{CdCl}_{2} \cdot$ TMEDA and LiTMP go into 0.5 equiv and 1 equiv, respectively, 2,5diiodopyrazine (4) concomitantly forms (20\% yield) to the detriment of iodopyrazine (3) (59\% yield).

The formation of dimetalated species being described using zincate ${ }^{18}$ or manganate ${ }^{19}$ type bases, the use of 1 equiv of $\mathrm{CdCl}_{2} \cdot$ TMEDA and 3 equiv of LiTMP was attempted to deprotonate pyrazine. Under the same reactions conditions, the diiodide $\mathbf{4}$ was isolated in 58\% yield when the reaction was performed on a $2 \mathrm{mmol}$ scale. The protocol could be successfully transposed to a $25 \mathrm{mmol}$ scale, albeit providing compound $\mathbf{4}$ in a lower yield of $40 \%$ (Scheme 3).

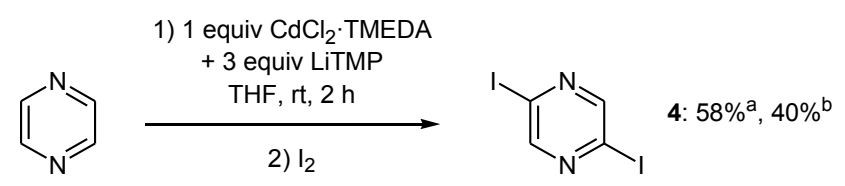

Scheme $3^{\text {a }} 2$ mmol scale. ${ }^{\mathrm{b}} 25 \mathrm{mmol}$ scale.

To our knowledge, the synthesis of 2,5-diiodopyrazine (4) has never been reported by other methods. Similar compounds such as 2-bromo-5-iodopyrazine ${ }^{20}$ and 2,5dibromopyrazine $^{21}$ have previously been prepared by diazotization of 5-bromopyrazinamine $(41 \%$ and $66 \%$ yield, respectively), the latter being accessible by bromination of pyrazinamine ( $75 \%$ yield). ${ }^{22}$

Such compounds can find applications as substrates for the synthesis of molecules endowed with biological ${ }^{23}$ or photophysical ${ }^{24}$ properties.

Reactions were performed under argon atmosphere. THF was distilled over sodium/benzophenone. Liquid chromatography separations were achieved on silica gel Merck Geduran Si 60 (40$63 \mu \mathrm{m})$. Melting points were measured on a Kofler apparatus. ${ }^{1} \mathrm{H}$ and ${ }^{13} \mathrm{C}$ Nuclear Magnetic Resonance (NMR) spectra were recorded at 200 and $50 \mathrm{MHz}$, respectively, on a Bruker ARX-200 spectrometer. ${ }^{1} \mathrm{H}$ chemical shifts $(\delta)$ are given in ppm relative to the solvent residual peak, and ${ }^{13} \mathrm{C}$ chemical shifts relative to the central peak of the solvent signal. ${ }^{25}$ IR spectra were taken on a Perkin Elmer Spectrum 100 spectrometer. High resolution mass spectra measurements and elemental analyses were performed at the CRMPO in Rennes (Centre Régional de Mesures Physiques de l'Ouest) using a Micromass MS/MS ZABSpec TOF instrument in EI mode and a Thermo-Finnigan Flash EA 1112 CHNS analyzer, respectively.

\section{Gram-Scale Synthesis of 2,5-Diiodopyrazine (4).}

To a stirred, cooled $\left(\begin{array}{ll}0 & \left.{ }^{\circ} \mathrm{C}\right) \\ \end{array}\right.$ tetramethylpiperidine $(13 \mathrm{~mL}, 75 \mathrm{mmol})$ in THF $(25 \mathrm{~mL})$ were successively added BuLi (1.6 M hexanes solution, $75 \mathrm{mmol})$ and $\mathrm{CdCl}_{2}$.TMEDA (7.5 g, $\left.25 \mathrm{mmol}\right)$. The mixture was stirred for 15 min at $0{ }^{\circ} \mathrm{C}$ before introduction of pyrazine $(2.0 \mathrm{~g}, 25 \mathrm{mmol})$. After $2 \mathrm{~h}$ at room temperature, a solution of $\mathrm{I}_{2}(14 \mathrm{~g}, 75 \mathrm{mmol})$ in THF $(25 \mathrm{~mL})$ was added. The mixture was stirred overnight before addition of an aqueous saturated solution of $\mathrm{Na}_{2} \mathrm{~S}_{2} \mathrm{O}_{3}(40 \mathrm{~mL})$ and extraction with AcOEt $(3 \times 40 \mathrm{~mL})$. The combined organic layers were dried over $\mathrm{MgSO}_{4}$, filtered and concentrated under reduced pressure. Purification by flash chromatography on silica gel (eluent: heptane/ $\mathrm{CH}_{2} \mathrm{Cl}_{2} 100 / 0$ to $80 / 20$ ) gave $3.3 \mathrm{~g}$ (40\%) of 2,5-diiodopyrazine as a yellow powder.

Mp $141^{\circ} \mathrm{C}$.

${ }^{1} \mathrm{H}$ NMR $\left(\mathrm{CDCl}_{3}\right): \delta 8.63(\mathrm{~s}, 2 \mathrm{H})$.

${ }^{13} \mathrm{C} \mathrm{NMR}\left(\mathrm{CDCl}_{3}\right): \delta 116.6\left(\mathrm{C}_{2}\right.$ and $\left.\mathrm{C}_{5}\right), 154.1\left(\mathrm{C}_{3}\right.$ and $\left.\mathrm{C}_{6}\right)$.

IR (ATR): $v$ 3048, 1431, 1421, 1384, 1267, 1121, 1104, 1004 and $886 \mathrm{~cm}^{-1}$.

HRMS: calcd for $\mathrm{C}_{4} \mathrm{H}_{2} \mathrm{I}_{2} \mathrm{~N}_{2}$ : 331.8307, found: 331.8297 .

Anal. Calcd for $\mathrm{C}_{4} \mathrm{H}_{2} \mathrm{I}_{2} \mathrm{~N}_{2}: \mathrm{C}, 14.48 ; \mathrm{H}, 0.61 ; \mathrm{N}, 8.44$. Found: C, $14.31 ; \mathrm{H}, 0.69 ; \mathrm{N}, 8.48 \%$. 


\section{Acknowledgment}

The authors gratefully acknowledge the financial support of Région Bretagne (to J.-M. L.), MESRS of Algeria (to G. B.) and Rennes Métropole.

\section{References}

(1) (a) Katritzky, A. R. Handbook of Heterocyclic Chemistry, $1^{\text {st }}$ ed.; Pergamon: New York, NY, 1985. (b) Eicher, T.; Hauptmann, S.; Speicher, A. The Chemistry of Heterocycles, $2^{\text {nd }}$ ed., Wiley-VCH, 2003, Chapter 6.

(2) (a) Gschwend, H. W.; Rodriguez, H. R. Org. React. 1979, 26, 1-360. (b) Beak, P.; Snieckus, V. Acc. Chem. Res. 1982, 15, 306-312. (c) Snieckus, V. Chem. Rev. 1990, 90, 879933. (d) Gant, T. G.; Meyers, A. I. Tetrahedron 1994, 50, 2297-2360. (e) Schlosser, M. Organometallics in Synthesis, $2^{\text {nd }}$ ed.; Wiley: New York, 2002, Chapter I.

(3) Schlosser, M. J. Organomet. Chem. 1967, 8, 9-16.

(4) Lochmann, L. Eur. J. Inorg. Chem. 2000, 7, 1115-1126.

(5) Caubère, P. Chem. Rev. 1993, 93, 2317-2334.

(6) For reviews, see: (a) Mulvey, R. E. Organometallics 2006, 25, 1060-1075. (b) Mulvey, R. E.; Mongin, F.; Uchiyama, M.; Kondo, Y. Angew. Chem. Int. Ed. 2007, 46, 3802-3824.

(7) (a) Krasovskiy, A.; Krasovskaya, V.; Knochel, P. Angew. Chem. Int. Ed. 2006, 45, 2958-2961. See also: (b) Wunderlich, S. H.; Knochel, P. Angew. Chem. Int. Ed. 2007, 46, 7685-7688.

(8) (a) Kondo, Y.; Shilai, M.; Uchiyama, M.; Sakamoto, T. J. Am. Chem. Soc. 1999, 121, 3539-3540. (b) Uchiyama, M.; Miyoshi, T.; Kajihara, Y.; Sakamoto, T.; Otani, Y.; Ohwada, T.; Kondo, Y. J. Am. Chem. Soc. 2002, 124, 8514-8515. (c) Barley, H. R. L.; Clegg, W.; Dale, S. H.; Hevia, E.; Honeyman, G. W.; Kennedy, A. R.; Mulvey, R. E. Angew. Chem. Int. Ed. 2005, 44, 6018-6021. (d) Clegg, W.; Dale, S. H.; Hevia, E.; Honeyman, G. W.; Mulvey, R. E. Angew. Chem. Int. Ed. 2006, 45, 2370-2374. (e) Clegg, W.; Dale, S. H.; Harrington, R. W.; Hevia, E.; Honeyman, G. W.; Mulvey, R. E. Angew. Chem. Int. Ed. 2006, 45, 2374-2377. (f) Clegg, W.; Dale, S. H.; Drummond, A. M.; Hevia, E.; Honeyman, G. W.; Mulvey, R. E. J. Am. Chem. Soc. 2006, 128, 7434-7435. (g) Uchiyama, M.; Matsumoto, Y.; Nobuto, D.; Furuyama, T.; Yamaguchi, K.; Morokuma, K. J. Am. Chem. Soc. 2006, 128, 8748-8750. (h) Uchiyama, M.; Kobayashi, Y.; Furuyama, T.; Nakamura, S.; Kajihara, Y.; Miyoshi, T.; Sakamoto, T.; Kondo, Y.; Morokuma, K. J. Am. Chem. Soc. 2008, 130, 472-480.

(9) (a) Quéguiner, G.; Marsais, F.; Snieckus, V.; Epsztajn, J. Adv. Heterocycl. Chem. 1991, 52, 187-304. (b) Godard, A.; Turck, A.; Plé, N.; Marsais, F.; Quéguiner, G. Trends Heterocycl. Chem. 1993, 3, 16-29. (c) Turck, A.; Plé, N.; Quéguiner, G. Heterocycles 1994, 37, 2149-2172. (d) Turck, A.; Plé, N.; Mongin, F.; Quéguiner, G. Tetrahedron 2001, 57, 4489-4505. (e) Chevallier, F.; Mongin, F. Chem. Soc. Rev. 2008, 37, 595-609.

(10) Plé, N.; Turck, A.; Couture, K.; Quéguiner, G. J. Org. Chem. 1995, 60, 3781-3786.
(11) Imahori, T.; Kondo, Y. J. Am. Chem. Soc. 2003, 125, 80828083.

(12) (a) Boudet, N.; Reddy Dubbaka, S.; Knochel, P. Org. Lett. 2008, 10, 1715-1718. (b) Mosrin, M.; Knochel, P. Org. Lett. 2008, 10, 2497-2500.

(13) Isobe, M.; Kondo, S.; Nagasawa, N.; Goto, T. Chem. Lett. 1977, 679-682.

(14) (a) Seggio, A.; Chevallier, F.; Vaultier, M.; Mongin, F. J. Org. Chem. 2007, 72, 6602-6605. See also: (b) Seggio, A.; Lannou, M.-I.; Chevallier, F.; Nobuto, D.; Uchiyama, M.; Golhen, S.; Roisnel, T.; Mongin, F. Chem. Eur. J. 2007, 13, 9982-9989; (c) L'Helgoual'ch, J.-M.; Seggio, A.; Chevallier, F.; Yonehara, M.; Jeanneau, E.; Uchiyama, M.; Mongin, F. J. Org. Chem. 2008, 73, 177-183.

(15) L'Helgoual'ch, J.-M.; Bentabed-Ababsa, G.; Chevallier, F.; Yonehara, M.; Uchiyama, M.; Derdour, A.; Mongin, F. Chem. Commun., accepted for publication.

(16) Wittig, G.; Meyer, F. J.; Lange, G. Liebigs Ann. Chem. 1951, 571, 167-201.

(17) Kedarnath, G.; Kumbhare, L. B.; Jain, V. K.; Phadnis, P. P.; Nethaji, M. Dalton Trans. 2006, 2714-2718.

(18) (a) Clegg, W.; Dale, S. H.; Hevia, E.; Hogg, L. M.; Honeyman, G. W.; Mulvey, R. E.; O'Hara, C. T. Angew. Chem. Int. Ed. 2006, 45, 6548-6550. (b) Armstrong, D. R.; Clegg, W.; Dale, S. H.; Graham, D. V.; Hevia, E.; Hogg, L. M.; Honeyman, G. W.; Kennedy, A. R.; Mulvey, R. E. Chem. Commun. 2007, 598-600.

(19) (a) Garcia-Álvarez, J.; Kennedy, A. R.; Klett, J.; Mulvey, R. E. Angew. Chem. Int. Ed. 2007, 46, 1105-1108. (b) Carrella, L. M.; Clegg, W.; Graham, D. V.; Hogg, L. M.; Kennedy, A. L.; Klett, J.; Mulvey, R. E.; Rentschler, E.; Russo, L. Angew. Chem. Int. Ed. 2007, 46, 4662-4666.

(20) Pieterse, K.; Lauritsen, A.; Schenning, A. P. H. J.; Vekemans, J. A. J. M.; Meijer, E. W. Chem. Eur. J. 2003, 9, 5597-5604.

(21) Ellingson, R. C.; Henry, R. L. J. Am. Chem. Soc. 1949, 71, 2798-2800.

(22) Itoh, T.; Kato, S.; Nonoyama, N.; Wada, T.; Maeda, K.; Mase, T.; Zhao, M. M.; Song, J. Z.; Tschaen, D. M.; McNamara, J. M. Org. Process Res. Dev. 2006, 10, 822 828.

(23) See for example: (a) Tonsiengsom, F.; Miyake, F. Y.; Yakushijin, K.; Horne, D. A. Synthesis 2006, 49-54; (b) Garg, N. K.; Stoltz, B. M. Tetrahedron Lett. 2005, 46, 24232426.

(24) For recent examples, see: (a) Saito, R.; Machida, S.; Suzuki, S.; Katoh, A. Heterocycles 2008, 75, 531-536; (b) Kojima, T.; Nishida, J.-i.; Tokito, S.; Tada, H.; Yamashita, Y. Chem. Commun. 2007, 1430-1432; (c) Marcaccio, M.; Paolucci, F.; Fontanesi, C.; Fioravanti, G.; Zanarini, S. Inorg. Chim. Acta 2007, 360, 1154-1162; (d) Tsubomura, T.; Enoto, S.; Endo, S.; Tamane, T.; Matsumoto, K.; Tsukuda, T. Inorg. Chem. 2005, 44, 6373-6378.

(25) Gottlieb, H. E.; Kotlyar, V.; Nudelman, A. J. Org. Chem. 1997, 62, 7512-7515. 
Graphical abstract:

$$
\underset{\substack{25 \mathrm{mmol} \text { scale } \\ 40 \% \text { yield }}}{\stackrel{\text { dimetalation-diiodination }}{\longrightarrow}}
$$

Short title:

Synthesis of 2,5-diiodopyrazine 